\title{
Diseases in insects produced for food and feed
}

Eilenberg, Jørgen; Vlak, J.M.; Nielsen-Leroux, C.; Cappellozza, S.; Jensen, Annette Bruun

Published in:

Journal of Insects as Food and Feed

DOI:

10.3920/JIFF2014.0022

Publication date:

2015

\section{Document version}

Publisher's PDF, also known as Version of record

Citation for published version (APA):

Eilenberg, J., Vlak, J. M., Nielsen-Leroux, C., Cappellozza, S., \& Jensen, A. B. (2015). Diseases in insects produced for food and feed. Journal of Insects as Food and Feed, 1(2), 87-102.

https://doi.org/10.3920/JIFF2014.0022 


\title{
Diseases in insects produced for food and feed
}

\author{
J. Eilenberg ${ }^{1 *}$, J.M. Vlak ${ }^{2}$, C. Nielsen-LeRoux ${ }^{3}$, S. Cappellozza ${ }^{4}$ and A.B. Jensen ${ }^{1}$ \\ ${ }^{1}$ University of Copenhagen, Department of Plant and Environmental Sciences, Thorvaldsensvej 40, 1871 Fredriksberg C., \\ Denmark; ${ }^{2}$ Wageningen University, Laboratory of Virology, Droevendaalsesteeg 1, 6700 AA Wageningen, the Netherlands; \\ ${ }^{3}$ INRA, UMR 1319 Micalis-AgroParisTech, AgroParisTech UMR Micalis, 78352 Jouy en Josas, France; ${ }^{4}$ Consiglio per la \\ Ricerca in Agricoltura e l'Analisi dell'Economia Agraria, Honeybee and Silkworm Research Unit, Padua Seat, Via Eulero \\ 6a, 35143 Padova, Italy; jei@plen.ku.dk
}

Received: 16 September 2014 / Accepted: 22 January 2015

(c) 2015 Wageningen Academic Publishers

REVIEW ARTICLE

\begin{abstract}
Increased production of insects on a large scale for food and feed will likely lead to many novel challenges, including problems with diseases. We provide an overview of important groups of insect pathogens, which can cause disease in insects produced for food and feed. Main characteristics of each pathogen group (viruses, bacteria, fungi, protists and nematodes) are described and illustrated, with a selection of examples from the most commonly produced insect species for food and feed. Honeybee and silkworm are mostly produced for other reasons than as human food, yet we can still use them as examples to learn about emergence of new diseases in production insects. Results from a 2014 survey about insect diseases in current insect production systems are presented for the first time. Finally, we give some recommendations for the prevention and control of insect diseases.
\end{abstract}

Key words: disease control, insect diseases, insects for food and feed, insect pathogens

\section{Introduction}

The current endeavours to produce insects on a large scale for food and feed will likely lead to many novel challenges. Animals brought into domestication and separated from their natural habitats are susceptible to infectious diseases, and insects are no exception. Insect diseases (caused by insect pathogens) can initiate dramatic epidemics in host insect populations in nature, leading to massive mortality and significant population decline. Insect pathogens can also inflict sub-lethal effects which may reduce fitness. For example, infections may result in reduced fertility, reduced ability to move, and higher vulnerability to predators (Vega and Kaya, 2012). In large scale production systems both lethal and sub-lethal insect disease effects may cause serious damage; thus monitoring, prevention and control of diseases are essential. When insects are mass-reared for food and feed they can come into contact with pathogens, which might not be typical of their natural habitat. Also, workers in rearing facilities may carry various kinds of microorganisms, including insect pathogens or vertebrate pathogens, on themselves or their clothing (Cohen, 2004).
In a broader, ecological context, development of insect diseases in production systems may spread out from the facilities and into non-target insect populations, which then suffer. Finally, there is also a potential risk for human health, if the insect based food or feed is contaminated with harmful microorganisms (for example from insects reared on manure).

The Insecta is one of the largest taxonomic classes of living organisms (accommodating probably more than one million species). Many entomopathogenic microorganisms are known, although mostly from arthropods of agricultural or human health importance. Studies of insect diseases have, from an applied perspective, been based on either the goal to control such diseases in insect production systems, or to use insect pathogens as biological control agents of insect pests. Studies to control diseases in insect production systems historically focused mostly on the two main insect species maintained in large quantities: the honeybee (Apis mellifera) and the silkworm (Bombyx mori), which have a long history of domestication. There are decades and even centuries of experience with diseases in these two insect 
species (Bassi, 1835, 1836; James and Li, 2012; Pasteur, 1870) and therefore these animals are models to understand insect diseases and recognise problems in production of additional insect species for food and feed. Many insect pathogens (e.g. almost all viruses) are very host specific, while others (e.g. some bacteria and fungi) have a broader host range. Some insect pathogens can create epidemics with high mortality and striking symptoms on the hosts (Roy et al., 2006), while others may cause chronic or asymptomatic infections for an extended period of time with scarce or no direct mortality (Lange and Lord, 2012). It is therefore essential to acquire knowledge of the biology of the particular production insect species and their associated diseases.

Our goal is to provide an overview of some main insect diseases caused by microorganisms and viral pathogens among insects that are considered or already in use for food and feed, how to diagnose these diseases and provide strategies to control them. Our focus is on insects in production systems, thus we do not discuss diseases in insects collected from the natural environment. We focus therefore on a limited number of important insect species, which are currently produced commercially for food and/ or feed (El Boushy, 1991; Hwangbo et al., 2009; Van Huis et al., 2013):

- Orthoptera: Acheta domesticus, Grylloides sigillatus, Locusta migratoria and Schistocerca gregaria;

- Lepidoptera: B. mori and Galleria mellonella;

- Coleoptera: Tenebrio molitor and Zophobas astratus/ morio;

- Hymenoptera: A. mellifera;

- Diptera: Hermetia illucens and Musca domestica.

Our examples and illustrations are mostly from infections in these insect species. Much research on diseases in some of these insects has been performed because they are indeed also pest insects in plant crops, husbandry or in storages (L. migratoria, S. gregaria, G. mellonella T. molitor, $M$. domestica) and there is an interest to control them biologically using for example insect pathogens. Concerning B. mori and A. mellifera, they are primarily produced for other reasons than human food or animal feed, but both species are edible and have been used traditionally as human food in various parts of the world (Chen et al., 1998; Defoliart, 1994; Van Huis et al., 2013). Both species are now also considered in the modern and even unusual application of insects as human food (Tong et al., 2011; www.nordicfoodlab.org).

In order to understand to what extent commercial producers are aware of insect diseases, we carried out a small survey among known producers and discuss the outcome. Finally, we discuss prevention and control strategies and indicate where we see the most urgent research needs. In general, we recommend Vega and Kaya (2012) and Lacey (2012) for updated, detailed information about the various groups of insect pathogens and methods to diagnose and study them. Here we present a synopsis for the convenience of the reader. In our review below, parasitoids and predators affecting production insects are not included, and also, we do not discuss insects as passive vectors of microorganisms and viruses, which are involved in human diseases such as arboviruses, Plasmodium, etc.

\section{Short biological characterisation of main insect pathogen groups}

\section{Viruses}

Viruses infect insects predominantly by oral uptake. Typical symptoms of baculovirus-infected insects are that the body of an infected larva swells (Figure 1I), shows a change in colour and the insect becomes lethargic. In the case of baculovirus the body of an infected insect liquefies and virus particles are released (Figure $1 \mathrm{H}$ ). Some virus diseases are characterised by abnormal development of certain parts of infected insects, for example deformed wings (Figure 1J) in the case of iflaviruses. Viruses are obligate intracellular pathogens which need host cells to replicate. Viral genetic material (viral genome) is made up of different forms of DNA (DNA-virus) or RNA (RNA-virus) and is enclosed in a protein coat (capsid) and sometimes a lipoprotein envelope (Harrison and Hoover, 2012). The genetic material and the surrounded protein are called nucleocapsid and the entire structure is called a virion or virus particle. Virions of the different virus families have different forms and shapes (Figure 2G and 3) and can only be seen via phase-contrast or electron microscopy. A virion represents the smallest infectious entity and is sometimes vulnerable but often persistent outside its natural host. After entry of a virion into a 'permissive' host cell (a susceptible one, where the virus is 'permitted' to replicate) the viral genetic material takes control of the cell's machinery, and begins to produce viral proteins, which will be used to generate new viral particles for systemic infection. As a consequence, this process often but not always causes the death of the host cells and the release of virus particles into the environment to initiate a new round of infection.

Currently there are 2,284 virus species recognised by the International Committee on Taxonomy of Viruses (Adams and Bonami, 1991; King et al., 2012), which are accommodated into 73 virus families. The various virus families are often unrelated and have, in contrast to organisms (tree of life), evolved independently and during different geological time zones. Viruses are the smallest pathogens (except for viroids in plants) known to mankind and can be detected by a variety of mainly molecular techniques, including enzyme-linked immunosorbent assay (ELISA) and polymerase chain reaction (PCR). Currently, there are 24 viral taxa with members infecting invertebrates, whereas only the taxa Ascoviridae, Baculoviridae and 

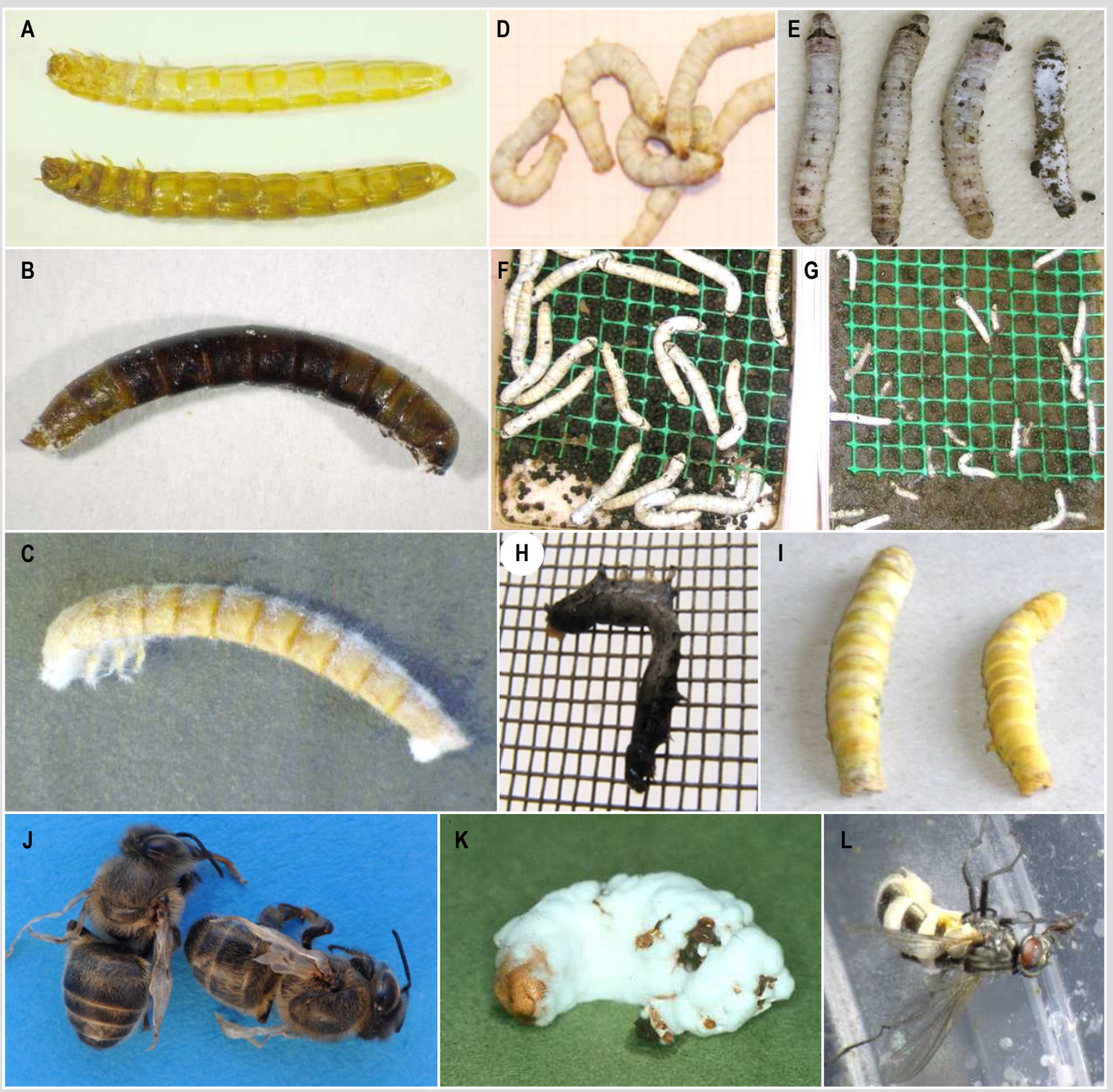

Figure 1. Symptoms of infections on insects. (A) Above: uninfected larvae of mealworm Tenebrio molitor; below: mealworm infected with nematode Steinernema feltiae. Note discoloured body. (B) Larva of mealworm infected with unknown bacteria. Such bacterial infections may also be caused by growth by saprotrophs after the death of the insect from other reasons. (C) Larva of mealworm infected with the fungus Beauveria bassiana. Note the beginning outgrowth of fungal structures from insect cadaver. (D) Healthy $5^{\text {th }}$ instar larvae of silkworm (Bombyx mori). (E) Early symptoms of infections by the fungus B. bassiana in B. mori larvae ( $5^{\text {th }}$ instar): discolour and on larva at right outgrowth of fungus. ( $F$ and $\left.G\right)$ Silkworm $B$. mori larvae $\left(5^{\text {th }}\right.$ instar) reared with artificial diet and infected by the bacterium Enterococcus mundtii (Gram-positive); $\mathrm{F}=$ control; $\mathrm{G}=\mathrm{E}$. mundtii infected larvae. Infected larvae have a much reduced size and weight. (H) Baculovirus-infected Spodoptera exigua larva; typical post mortem posture is the soft body of the killed insects, from where infective virions are released. (I) BmNPV (virus) symptoms in $5^{\text {th }}$ instar larvae of a yellow-cocoon B. mori strain. (J) Honeybees (Apis mellifera) infected by deformed wing virus. (K) European cockchafer Melolontha melolontha infected with the fungus Beauveria brongniartii. The insect cadaver is completely covered by conidiophores, which have emerged all over the dead insect's body and have produced infective conidia. (L) House fly (Musca domestica) killed by fungus Entomophthora muscae sensu lato. Note whitish fungus conidiophores growing out between segment on abdomen, producing infective conidia, which are discharged. Photos: A, B, and C by E. Erin Morris; D, E, F, G and I by Silvia Cappellozza; H by Just M. Vlak; J by Ruedi Ritter; K by Jørgen Eilenberg; and L by Henrik de Fine Licht. 


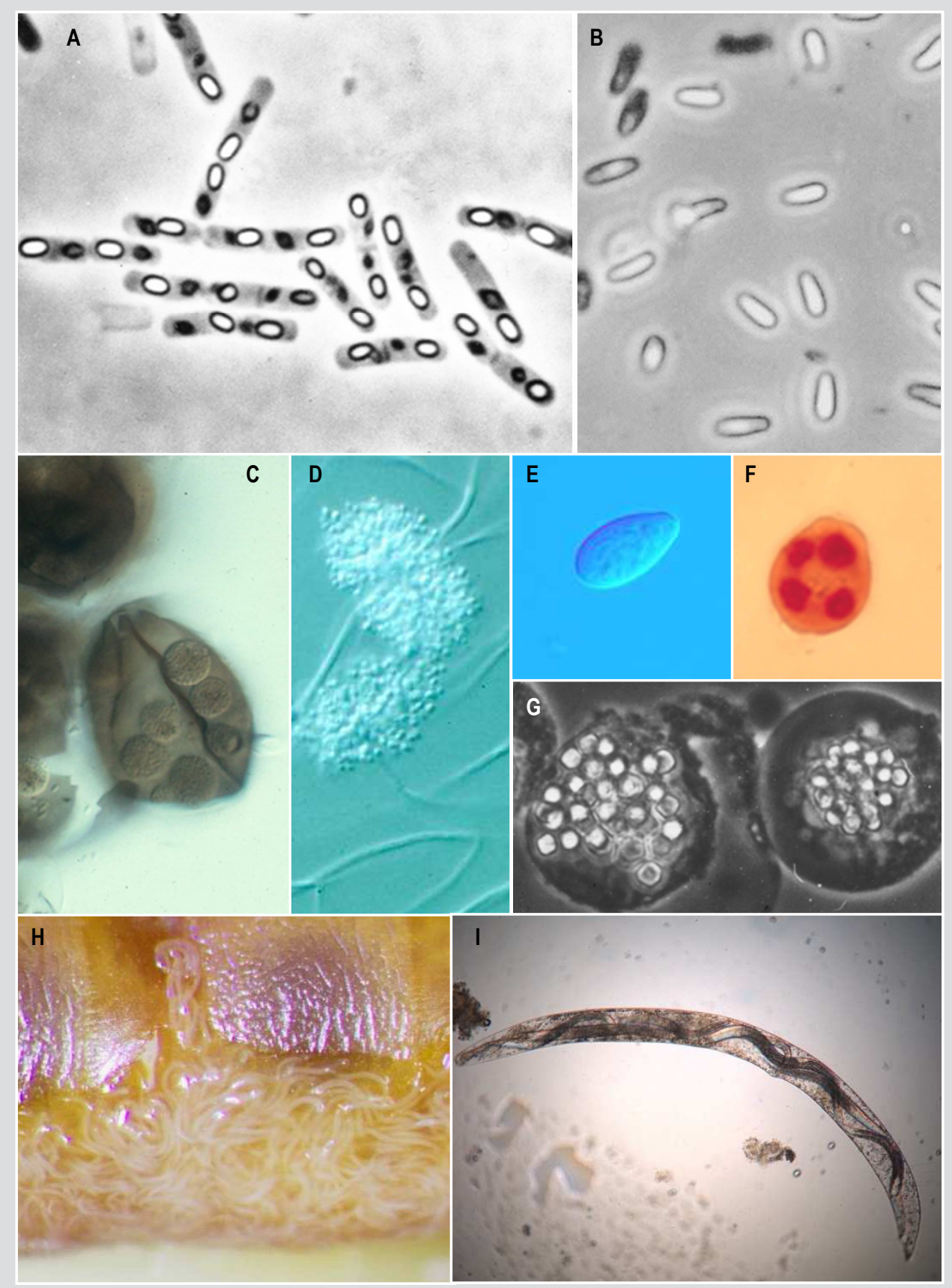

Figure 2. Microscopic illustrations of selected insect pathogens of relevance. (A) Bacteria (Bacillus thuringiensis) 2-3 microns in length with spores (ovoid white) and toxin crystals (pyramidal shaped); (B) Spore of the microsporidium Cystosporogenes deliaradicae. Spores of insect pathogenic microsporidia are typically 2-6 microns; (C) The fungus Ascosphaera apis; (D) Spore clusters of the fungus Beauveria bassiana. The conidia are globose and approx. 3 microns in diameter; (E and F) Conidia from entomophthoralean fungi from the genera (E) Pandora and (F) Entomophthora. Conidia from Entomophthorales are mostly between 15 and 40 microns in length. Nuclei staining is shown on F; (G) Two baculovirus-infected Sf21 insect cells. Cell diameter is approx. 20 microns, polyhedron diameter is approx. 3 microns; (H) Nematodes (Steinernema feltiae) filling the body of the infected insect (Tenebrio molitor); (I) Adult S. feltiae filled with offspring. Adult nematode is approx. 200 microns in length. Photos: A by Christina Nielsen-Leroux; B, C, D, E and F by Jørgen Eilenberg; $G$ by Just M. Vlak; and H and I by E. Erin Morris. 


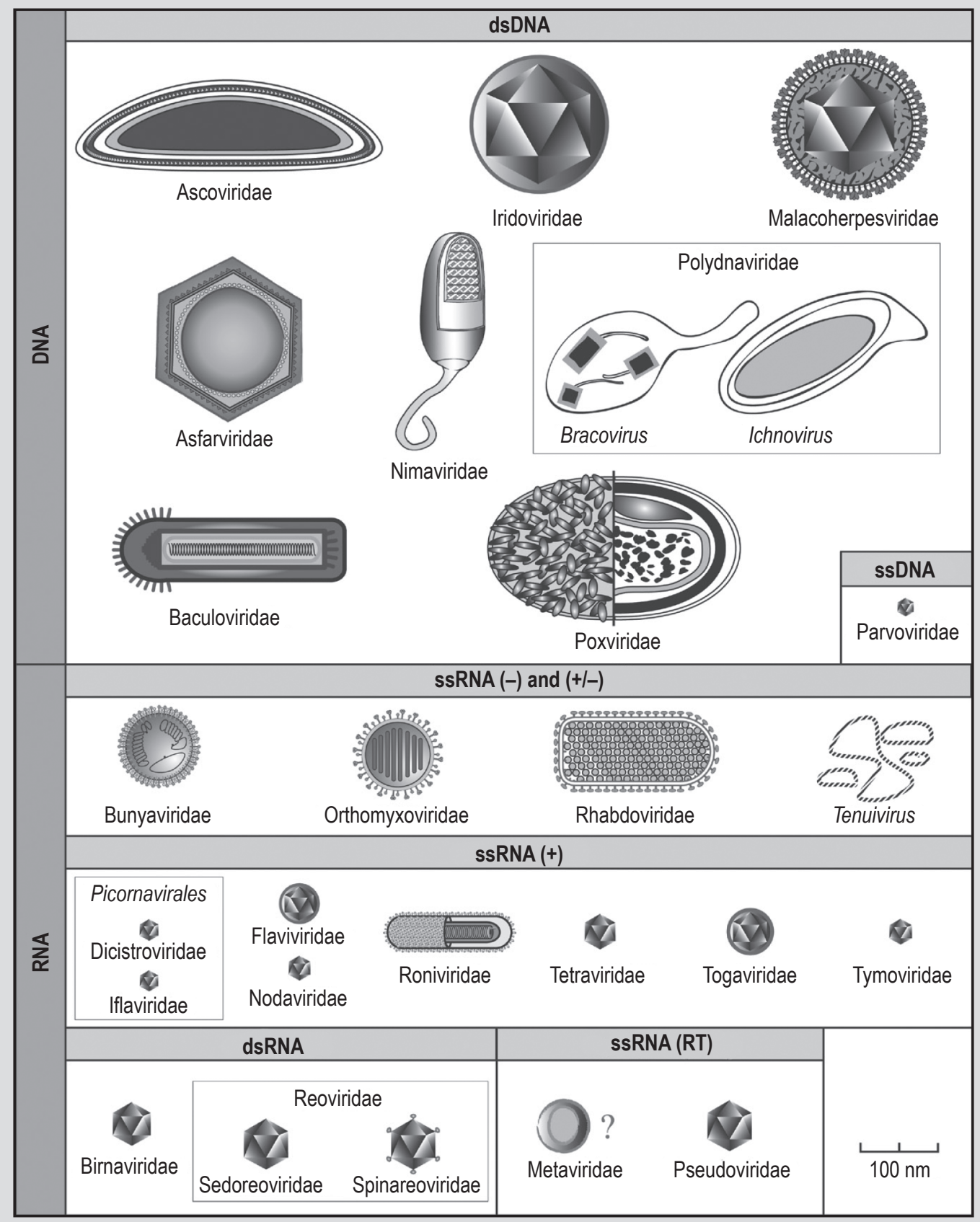

Figure 3. Virus taxa infecting invertebrates. Single strand (ss) and double strand (ds) DNA viruses; single (ss) and double strand (ss) RNA viruses, positive (+) and negative (-) stranded, mainly from insects and crustaceans (King et al., 2012; reproduced with permission from Elsevier).

Polydnaviridae (DNA-viruses) and Discistroviridae and Iflaviridae (positive-strand RNA-viruses) are solely insect pathogens (Figure 3). The other taxa have members in other invertebrates (shrimp) or in vertebrates. In many cases the association between insects and viruses is non-pathogenic or asymptomatic. Insects can also be carriers of such viruses targeting other organisms (plants or vertebrates). Examples from these arboviruses are yellow fever, dengue, West-Nile and Chikungunya virus that are vectored by mosquitoes to humans. Wanaratana et al (2013) documented that $M$. domestica even may vector avian influenza virus HPAI$\mathrm{H} 5 \mathrm{~N} 1$, although the virus did not infect and replicate in the house flies. 
Most entomopathogenic viruses known are from insects of agricultural importance. However, for most insect species, including the ones used for food and feed, little to no research has been conducted on viral diseases. Latent or asymptomatic virus infections in insects are quite common and often compromise insect rearing systems, where insects are present in high densities so that disease transmission rates increase. For example, in the production of the house cricket $A$. domesticus, a densovirus (AdDNV) frequently occurs and has been known to exist at endemic levels in Europe for at least 35 years (Liu et al., 2011). Infected $A$. domesticus crickets die from infection or become smaller and less active (Szelei et al., 2011). Weissmann et al. (2012) described a recent, rather dramatic situation for A. domesticus producers in USA. A. domesticus AdDNV caused severe epidemics in the production systems in the USA, with huge losses in production as a result. The authors actually suggested replacement of $A$. domesticus by $G$. sigillatus to avoid this virus disease. Other possibilities for replacement of $A$. domesticus could be members from the genus Gryllus (Gryllus assimilis and Gryllus bimaculatus) since they seem resistant to AdDNV (Szelei et al., 2011). AdDNV is thus an example where a pathogenic virus can be detrimental to insect rearing systems and by that it can be the reason for changes in production systems or even a change in the species used for production.

Several other viruses have been found in crickets, for example Jakob et al. (2002) isolated a cricket iridovirus (CrIV) from both Gryllus campestris and A. domesticus. This iridovirus CrIV could infect both $A$. domesticus and other orthopterans (G. campestris, G. bimaculatus and L. migratoria) and can even be fatal (Kleespies et al., 1999). Thus, to avoid this virus it will not be sufficient to replace $A$. domesticus with another orthopteran. Another example of a virus infecting a production insect is a salivary gland virus (MdSGHV, Hytrosaviridae) infecting and sterilising adult $M$. domestica (Salem et al., 2009). Naturally, up to 5\% infections can be found in populations of $M$. domestica (Geden et al., 2011). The virus has a peculiar way of transmission, orally via salivary gland excretion (Lietze et al., 2009).

It appears very difficult to distinguish among latent viruses, i.e. non-infective and non-replicating viruses, which can be transformed to an infective state by some stressors (Fuxa et al., 1999) or persistent viruses (low-level of replication) (Hughes et al., 1997). Even though viral genome integration in the host cell was demonstrated in B. mori (Kok et al., 1983) and in G. mellonella (Miryuta et al., 1985) it is very difficult to prove that the transfer of the virus from the mother to the progeny is a transovarial transmission within the eggs due to a latent infection rather than a transovum transmission owing to egg surface contamination (Cory and Myers, 2003). The distinguishing is important when a control strategy is chosen, for example egg surface sterilisation. It is anyway very difficult to control viruses on the egg surface even in the laboratory since surface sterilisation of eggs is often incapable of complete pathogen elimination (Kukan, 1999; Myers et al., 2000).

As seen from the above-mentioned examples of virus infections among insects produced for food and feed, viruses may cause different symptoms and also the level of specificity varies. Virus transmission can sometimes occur among taxonomically related species. Crustacean diseases are not part of our review, but an interesting example of a virus disease in crustaceans should be mentioned, namely Penaeus merguiensis densovirus (PmergDNV) which occurs naturally in prawn production (P. merguiensis), where it is an important disease and must be controlled (Owens et al., 2011). The virus is experimentally infective to crabs (Portunus pelagicus) and also to A. domesticus (Fauce and Owens, 2008). So, invertebrate viruses sometimes can cross the species barrier and this poses a potential risk to other arthropod production systems.

\section{Bacteria}

Most bacteria infect the host by oral infection; however, infection can in some cases also occur by being vectored by nematodes or parasitoids. Bacterial infections in insects often cause that infected insects become discoloured or dark (Figure 1F and 1G). Bacteria associated with insects vary from symbionts or commensals to entomopathogens or saprophytes (bacteria which consume dead plant/animal tissue for food). Bacteria are small (0.1 to $2 \mu \mathrm{m})$ unicellular microbes, some form spores (a dormant, dry and very heat resistant feature) while others are less protected. Bacteria have different shapes, often small rods (bacilli), circular forms (cocci) or spiral and may occur singly, in groups or in chains. Some opportunistic insect pathogenic bacteria do not need insects for their development and survival and can therefore last for long time in poorly cleaned rearing facilities. The identification of bacterial pathogen species responsible for infections needs observation in a light microscope with 400-1000× magnification using phase contrast objectives, with which the presence of spores, vegetative bacteria (rods/cocci) and toxin inclusion bodies for species like Bacillus thuringiensis (Bt) can be visualised (Figure 2A). Further identification can be done with specific genetic markers (primers 16S PCR and sequencing) or for Bt with global primer sets for core cry toxin encoding genes.

Insect pathogenic bacteria are found in several bacterial genera (Bacillus, Serratia, Pseudomonas, Paenebacillus, Micrococcus, Xenorhabdus, etc.; for reviews see Vallet-Gely et al., 2008, and Jurat-Fuentes and Jackson, 2012). They all reproduce by simple division and under optimal conditions only a few bacteria are needed to start an infection, while a diseased insect cadaver may contain several hundreds of thousands of bacterial units resulting from generalised septicaemia. In most cases, bacterial insect diseases are 
associated with the larval stage. To be infective by the oral route these bacteria need to cross or destroy the intestinal barriers (Nielsen-Le Roux et al., 2012). When bacteria have spread into the insect body it becomes black due to melanisation (Figure 1B).

One of the most studied bacterial entomopathogens is Bt, which is used for microbial control of insect pests (Bravo et al., 2011). Natural strains of this species are commonly found in various environments, such as soil, dust, leaf surface and dead insects. Most Bt strains are active against only a limited number of insect species, (Van Frankenhuyzen, 2009) and this specificity is principally due to presence of toxins (Cry) associated in inclusions (Figure 2A), and more than 70 different Cry toxins have been sequenced today. Bt is a sporeforming bacterium and these spores can survive for years and are difficult to eliminate; therefore in a rearing facility a complete cleaning and removal of dead insects is necessary to inhibit the disease from spreading. While epizootics due to Bt are rare in nature, problems with Bt infections have occurred in silkworm production and in mass rearing of other lepidopterans (Lietze et al., 2010).

Other bacteria like Xenorhabdus spp. and Photorhabdus spp. are pathogens of numerous insects and are mutualists of nematodes from the family Heterorhabditidae and Steinernematidae, respectively (Nielsen-LeRoux et al., 2012). Bacterial infections of honeybee larvae are mainly caused by three species, Paenibacillus larvae, Paenibacillus alvei and Melissococcus plutonius (De Graaf et al., 2013; Forsgren et al., 2013; Table 1). Several Pseudomonas species, like Pseudomonas entomophila are also insect pathogens able to infect stressed insects (Fedhila et al., 2010; Liehl et al., 2006). Bacterial septicemia is due to different bacteria, mostly from the genera Serratia and Proteus, which are able to cross the peritrophic membrane barrier and penetrate through the midgut or enter through body surface wounds and capable of rapidly multiplying in the hemolymph (Kodama, 2001).
Among the insects which are reared for feed or food, some have been reported to be susceptible to bacteria. The larval stage of $M$. domestica is sensitive to infections from Brevibacillus laterosporus and B. thuringiensis israelensis (Zimmer et al., 2013). T. molitor is sensitive to Bt strains producing Cry3 toxins (Wu and Dean, 1996) and, under laboratory assays, to Aeromonas hydrophila (Noonin et al., 2011). A few Bt strains have also been found active against L. migratoria (Song et al., 2008). A. domesticus was shown to be infected by Serratia liquefaciens under laboratory conditions (Gray, 1997) and interestingly it was reported that sublethal infection of $A$. domesticus with $S$. marcescens resulted in increased egg laying (Adamo, 1999) pointing out that the presence of infectious bacteria may even stimulate the generation turn over. G. mellonella is susceptible to various bacteria and this insect is used as a model to study human or animal pathogens as for instance Listeria monocytogenes (Mukherjee et al., 2013).

\section{Fungi}

Insect pathogenic fungi can be found throughout the fungal kingdom but the majority of these fungi are found within three major groups, the Hypocreales, the Entomophthoromycota and the Ascosphaera (Boomsma et al., 2014). Most fungal diseases infect insects by penetration of the host cuticle, although one genus (Ascosphaera) infects orally. The life cycle of most insect pathogenic fungi includes infectious asexual spores (conidia) for transmission of the disease into a new host, and sexual spores, which ensure recombination and for some species winter survival of the fungus (Boomsma et al., 2014). Behavioural fever is an important self-cure of some fungal infections thanks to which infected insects deliberately move themselves to hotter places which are detrimental to the fungus, but not to the host. It has been documented to occur in several different insect orders (flies (Diptera), locusts (Orthoptera), and honeybees (Hymenoptera)) and with examples from several groups of insect pathogens (Anderson et al., 2013; Blanford and Thomas, 2001; Kalsbeek et al., 2001; Starks

Table 1. Examples of important insect diseases found in honeybee (Apis mellifera). For the viruses acute bee paralysis virus and deformed wing virus there are so far no recognised names of the diseases.

$\begin{array}{lll}\text { Group } & \text { Disease agent } & \text { Disease name } \\ \text { Virus } & \text { Acute bee paralysis virus (ABPV) (Dicistroviridae) } & \text { 'Acute bee paralysis virus' } \\ & \text { Deformed wing virus (DWV) (Iflaviridae) } & \text { 'Deformed wing virus' } \\ & \text { Sacbrood virus (SBV) (picorna-like virus) } & \text { Sacbrood } \\ \text { Bacteria } & \text { Paenibacillus larvae } & \text { American foulbrood } \\ & \text { Melissococcus plutonius } & \text { European foulbrood } \\ \text { Fungi } & \text { Ascosphaera apis } & \text { Chalkbrood } \\ & \text { Aspergillus sp. } & \text { Stonebrood } \\ \text { Microsporidia } & \text { Nosema apis } & \text { Nosemosis } \\ & \text { Nosema ceranae } & \end{array}$


et al., 2000). In many cases, morphological examination of fungal structures using light microscopy is sufficient to determine the pathogen to genus level, while determination to species level may require molecular tools.

The species of hypocrealean genera Beauveria (Figure $1 \mathrm{C}, 1 \mathrm{D}, 1 \mathrm{E}, 1 \mathrm{~K}$ and 2D), Metarhizium, Isaria (formerly Paecilomyces) and Lecanicillium (formerly Verticillium) are examples of important insect pathogenic species. In general, these fungi have a broad host range exemplified by the biological control agent Metarhizium brunneum which infects coleopteran, hemipteran and lepidopteran insects as well as ticks (from Acari). Through a combination of physical and chemical processes the conidia (less than 10 microns) penetrate the cuticular layers, followed by fungus growth in the haemolymph, toxin production and finally death of the infected host (Boomsma et al., 2014; Vega et al., 2012). Some hypocrealean species possess the ability to develop epidemics and produce spores that may survive in the environment for an extended period.

Fungi from Hypocreales commonly infect insects species that are produced for food and feed, including the Zophobas beetle which is otherwise considered rather resistant and disease free (Rangel et al., 2004). Siri et al. (2005) documented that Beauveria bassiana naturally infected adult $M$. domestica. Experimentally, $M$. domestica adult flies were susceptible to strains from both Metarhizium and Beauveria (Anderson et al., 2011). The above mentioned self-cure by behavioural fever for these infections has been shown for M. domestica infected with B. bassiana (Anderson et al., 2013). The same behavioural pattern is found in locusts, which are susceptible to infections from Beauveria and Metarhizium. Blanford and Thomas (2001) studied infections by Metarhizium acridium in $S$. gregaria. The fungus caused high mortality, but if infected hosts were allowed to thermoregulate, it resulted in much lower mortality. The length of the thermoregulation has importance for the outcome (Ouedraogo et al., 2004). Their studies proved that also L. migratoria did thermoregulate when infected by $M$. acridium. Crowding is another factor of importance for disease risk since it has been shown that $S$. gregaria reared under crowded conditions was more resistant to infections of $M$. acridium than solitary reared individuals (Wilson et al., 2002).

The two species T. molitor and G. mellonella are both highly susceptible to infections by hypocrealean fungi. This susceptibility has resulted in the extensive use of these insects as so called 'bait insects' to isolate hypocrealean fungi from soil (Meyling and Eilenberg, 2006; Sun and Liu, 2008). As was the case for S. gregaria, also T. molitor exhibited lower mortality to introduced Metarhizium anisopliae when grown in crowded conditions, explained by increased investment in the immune system and seen as a higher level of melanisation in T. molitor grown under crowded conditions (Barnes and Siva-Jothy, 2000), while inbreeding of T. molitor increased the susceptibility to B. bassiana (Rantala et al., 2010). The susceptibility to hypocrealean fungi is, however, not constant. T. molitor has been used as a model to elucidate if a functionally 'adaptive immunity' can be present in insects challenged with M. anisopliae (Moret and Siva-Jothy, 2003). Similarly G. mellonella developed some resistance to infection by $M$. anisopliae after constant selective pressure from $B$. bassiana (Dubovskiy et al., 2013). Fungi from the phylum Entomophthoromycota are known to develop rapid and striking epidemics in their host populations (Boomsma et al., 2014; Roy et al., 2006). Species from the orders Entomophthorales and Neozygitales (together often called entomophthoralean fungi) are exclusively pathogens of insects and Acari and are mostly very host specific, infecting only one or a few taxonomically related hosts. The conidia of entomophthoralean fungi are relatively large, mostly more than 20 microns in length (Figure $2 \mathrm{E}$ and 2F). Several species produce wall-less protoplasts after entering the insect hemolymph, and such protoplasts are not recognised as foreign organisms by the host innate immune system (Butt et al., 1996). After the death of the host short lived conidia are forcibly discharged from the insect cadaver (Figure 1L) and are quickly dispersed. Fungi from Entomophthorales are also capable of producing epidemics and induce behavioural changes in their hosts, such that moribund insects climb to the top of vegetation where they become fixed to it by fungal structures, insect legs, or biting onto it with their mandibles (Roy et al., 2006).

M. domestica is subjected to infection by several species from the genus Entomophthora (Lastra et al., 2006; Mullens et al., 1987). In Diptera, fungi from the genus Entomophthora have over time diverged much as have their host dipterans, by that documenting a long history of co-evolution (Jensen et al., 2009). A certain success in transmission of Entomophthora from its original host to other dipteran hosts was, however obtained by Jensen $e t$ al. (2006), although such transmission was accompanied by a less profound sporulation from the new host.

The genus Ascosphaera (phylum Ascomycota) contains species which solely live in close association with honeybees or solitary bees (James and Li, 2012; Jensen et al., 2013). Some species are saprotrophs feeding on, for example, pollen provisions while others are insect pathogens. The well-known species Ascosphaera apis (chalkbrood) infects honeybee larvae (Figure 2C, Table 1). Infection takes place by oral uptake of the sexual spores (asexual spores are unknown) by the bee larvae; these spores germinate in the gut of the larvae and later penetrate the peritrophic membrane and gut wall. New sexual spores are produced after the host dies. 


\section{Microsporidia and other protists}

Protists are a diverse group. Microsporidia are protists and were formerly regarded as closely related to animals. Multigene phylogenies, however, have revealed that they are close relatives to the kingdom fungi. An extensive updated review about microsporidia can be found in Solter and Bechnel (2012). Infection can be transmitted in two ways: orally via spores or vertically via eggs. Upon oral uptake of microsporidian spores, these spores germinate in the midgut of the insect. The germinated spores infect the epithelial cells of the midgut by a hollow polar filament with a unique ultrastructure and once inside a cell they multiply and form new spores, which are then transmitted to new hosts. Microsporidian spores are within the range of fungal or bacterial spores in size and can be viewed by light microscopy (Figure 2B). Microsporidia are mostly highly host specific, and can be chronically present in host populations without resulting in high mortality, however examples of highly virulent Microsporidia species exist and have been known to cause elevated losses in honeybees and silkworms. A common clade of Microsporidia includes the genera Nosema and Vairimorpha. Paranosema locusta is a well-known pathogen of $L$. migratoria mostly present as a chronic disease but also resulting in mortality of the host or resulting in lower fitness upon experimental infections (Maniania et al., 2008). P. locusta has proven an interesting interaction with fungi: at the phase of spore maturation of $P$. locusta in locusts, the insects became more susceptible to infections by the fungus M. acridium (Tokarev et al., 2011). The species Nosema bombycis infects silkworms (Table 2), while Nosema apis and Nosema ceranae infect honeybees (Fries et al., 2013; Table 1) and can be a serious threat to honeybees (Higes et al. 2008).

Other types of insect pathogenic protists include Amoebae, neogregarines and eugregarines (Lange and Lord, 2012), which often can be chronically present in the gut of infected hosts. Although not immediately or strongly lethal, they may cause reduced host fitness (reduced longevity, slower movements, and increased host susceptibility to other diseases). These protists are transmitted via contaminated food and therefore can be problematic in dense populations of insect in production facilities.

\section{Nematodes}

Nematodes are members of the animal phylum Nematoda and therefore are not microorganisms. However, they often are treated as insect pathogens, since the infection process and reproductive biology of insect pathogenic nematodes are similar to insect pathogenic microorganisms and also, since some important nematode genera Steinernema (Figure $2 \mathrm{H}$ and 2I) and Heterorhabditis carry with them symbiotic bacteria (Xenorhabdus and Photorabdus, respectively), which are essential for successful infection in the host (Lewis and Clarke, 2012). For the genera Steinernema and Heterorhabditis, the infective stage is the third instar juvenile I/J, which can penetrate into the host using natural openings like the mouth, anus or spiracles. The symbiotic bacteria are released into the hemocoel and subsequently release toxins, killing the host (Figure 1A). The nematodes present in the insect host feed on the dissolved insect tissue and on the bacteria. They develop into adults, which reproduce in the insect cadaver and produce a new generation of IJ's to leave the cadaver and infect new hosts.

Nematodes from the genera Steinernema and Heterorhabditis mostly have a broad host range and can infect several insect species produced for food and feed. For example, Heterorhabditis georgiana (and other species from that genus) could infect both $M$. domestica, A. domesticus and T. molitor (Shapiro-Ilan et al., 2009). Each insect species can also be susceptible to a range of nematodes, an example is T. molitor, which is susceptible to both Heterorhabditis bacteriophagae (Brown et al., 2006), S. feltiae and Steinernema affine (Nielsen and Philipsen 2004). Nematodes from the genera Steinernema and Heterorhabditis are dependent on a certain level of humidity in order to survive and infect. Therefore, they do

Table 2. Examples of important insect diseases found in silkworm Bombyx mori.

$\begin{array}{llll}\text { Group } & & \text { Disease agent } & \text { Disease name } \\ \text { Viruses } & \text { Baculoviridae } & \text { BmNPV, MNPV } & \\ & \text { Parvoviridae } & \text { BmDNV-1 } & \text { nucleopolyedrosis, multicapsid nucleopolyedrosis } \\ & \text { Bidensoviridae } & \text { DNV-2, DNV-3 } & \text { densonucleosis (different isolates) } \\ & \text { Reoviridae } & \text { BmCPV } & \text { cytoplasmic polyhedrosis } \\ & \text { Picornaviridae } & \text { BmIFV } & \text { infectious flacherie } \\ \text { Bacteria } & \text { Gram-positive } & \text { Enterococcus faecalis, Enteroccus faecium, Enteroccoccus mundtii } & \text { bacterial infectious flacherie } \\ & \text { Gram-negative } & \text { Serratia marcescens, Proteus mirabilis } & \text { septicemia } \\ \text { Fungi } & \text { Ascomycota } & \text { Beauveria bassiana, Aspergillus flavus, Aspergillus oryzae } & \text { muscardine, aspergillosis } \\ \text { Microsporidia } & \text { Nosema bombycis } & \text { pebrine }\end{array}$


normally not pose a danger to insects in rearing facilities, which are often kept in drier conditions. Also, S. feltiae, Steinernema bibionis and Heterorhabditis heliothidis have low survival in manure, thus it is unlikely that for example M. domestica larvae get infections (Georgis et al., 1987). However, nematodes could potentially cause problems if massive insect rearing in other types of wet wastes is developed further.

\section{Lessons learned from the emergence of diseases in insects produced for centuries}

The main lessons learned about diseases in insects produced for centuries are that the whole array of insect diseases can be expected to occur in production insects. Also, we can expect that new diseases emerge over time. In the early $19^{\text {th }}$ century the first honeybee diseases were described and today we find many types of insect pathogens in honeybees (Figure 1J; Table 1). Honeybees are kept outside, and thus prevention of disease transmission is less manageable compared to most other confined, insect rearing facilities. More than twenty viruses have been identified in honeybees and new viruses are found with few years interval (Figure 4); the most recent were found using high-throughput sequencing of RNA or DNA whole bee extract. Some of the viruses produce recognisable symptoms at sufficiently elevated titres (Figure 1J), but honeybee viruses generally persist chronically in populations at low levels without detectable symptoms. Viruses have been detected in all tissues and in all life stages, but high titres and symptoms are for most of the viruses to be found in pupae and adults, except sacbrood virus which is a larval disease. Since several viruses produce similar symptoms detection is most often performed by means of quantitative reverse transcription PCR (De Miranda et al., 2013).
Thousands of years of domestication and artificial selection of the silkworm (B. mori), established by man, have increased production and at the same time possibly decreased the robustness and resistance of this insect, so that it is currently vulnerable to several diseases (Figure 1D-G and 1I; Table 2). This should be considered as an example of the negative effects of long term mass rearing on insect fitness. Viruses usually account for 70-80\% losses in cocoon harvest due to disease incidence in silkworms ( $\mathrm{Lu}$, 1991). Four main types of virus diseases of the silkworm are known: nucleopolyhedrovirus, cytoplasmic polyhedrosis, infectious flacherie, and densonucleosis (Watanabe, 2002). As for honeybees, but less frequently, new virus diseases are discovered in silkworms over time (Figure 5). Massive bacterial outbreaks are rare in silkworms and are mostly due to inadequate rearing conditions or lack of hygiene. Bacterial infectious flacherie is due mostly to Enterococci (multiplying mostly in the alimentary canal) causing diarrhoea and progressive death of the infected insects.

\section{Emergence of diseases in insects produced for food and feed}

While honeybees and silkworms have been domesticated since ancient times, insects for food and feed have been an issue for a much shorter time period. Which disease patterns do we find in commercial production system? To address that we (J. Eilenberg and A.B. Jensen) sent in spring 2014 a one page questionnaire to companies and other people who produce insects for food and feed in larger quantities. The questionnaire asked for their experience with insect diseases in their production stock, the types of pathogens occurring, the effects on the host population, and the results from control measures. The responses from more than 20 producers in several countries were compiled

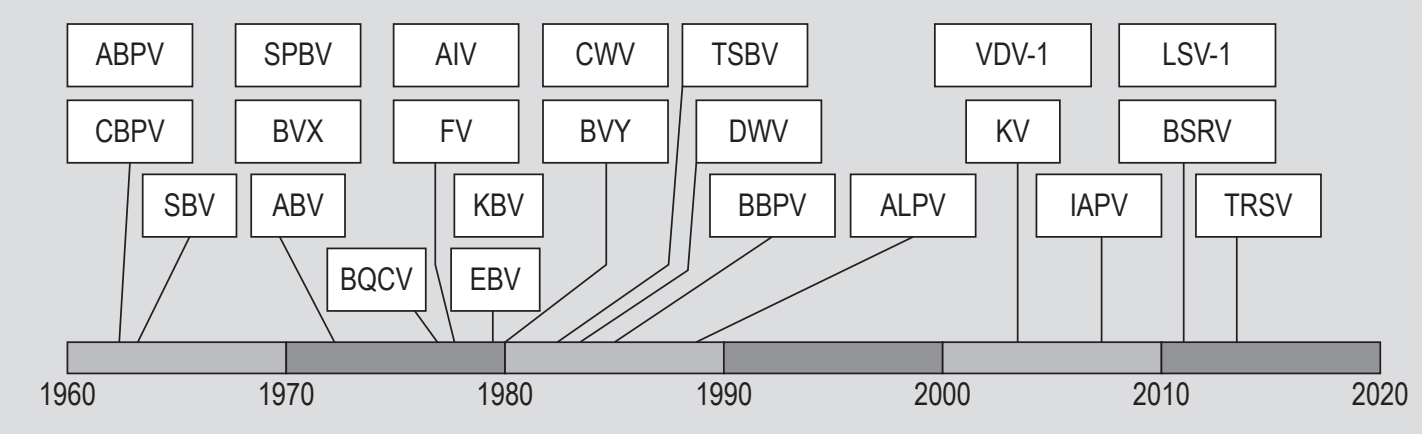

Figure 4. Emergence of new virus infections in honeybee (Apis mellifera) since 1960. The figure shows time of first documentation of major virus diseases in honeybees $(A B P V=$ acute bee paralysis virus; $A B V=$ Arkansas bee virus; $A I V=A$ pis iridescent virus; $A L P V=$ aphid lethal paralysis virus; $B B P V=$ Berkeley bee picorna-like virus; $B Q C V=$ black queen cell virus; $B S R V=B i g$ Sioux River virus; $B V X=$ bee virus $X ; B V Y=$ bee virus $Y ; C B P V=$ chronic bee paralysis virus; $C W V=$ cloudy wing virus; $D W V=$ deformed wing virus; $\mathrm{EBV}=\mathrm{Egypt}$ bee virus; $\mathrm{FV}=$ filamentous virus; $\mathrm{IAPV}=$ Israeli acute paralysis virus; $\mathrm{KBV}=\mathrm{Kashmir}$ bee virus; $\mathrm{KV}=$ Kakugo virus; LSV-1 = Lake Sinai virus; SBPV = slow bee paralysis virus; SBV = sacbrood virus; TRSV = tobacco ring spot virus; TSBV $=$ Thai sacbrood virus; VDV-1 = Varroa destructor virus-1). 


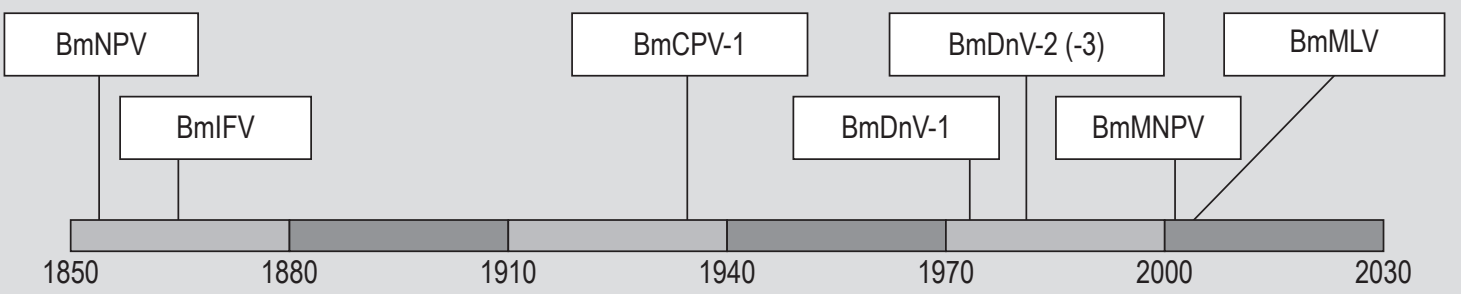

Figure 5. Emergence of new virus infections in silkworm (Bombyx mori) since 1856. The figure shows time of first documentation of major virus diseases in silkworms (BmNPV = B. mori nucleopolyhedrovirus; $B m I F V=B$. mori infectious flacherie virus; $B m C P V-1$ $=B$ mori cypovirus $-1 ; B m D n V-1=B$. mori densonucleosis virus $-1 ; B m D n V-2(-3)=B$ mori densonucleosis virus-2 (-3); BmMNPV $=B$. mori multiple nucleopolyhedrovirus; $B m M L V=B$. mori macula-like latent virus).

(Table 3). It appears that among the four insect species listed, much difference with respect to insect diseases exists. For the black soldier fly (H. illucens), none of the survey respondents mentioned disease problems. This also is confirmed by our check of literature and Internet search. Concerning house fly (M. domestica) and mealworm ( $T$. molitor), diseases have been present in production facilities and caused some troubles, but it seemed the diseases could be handled by relatively simple control measures. Then, for the house cricket (A. domesticus), several diseases have occurred. Virus diseases in particular have been so devastating that dramatic actions have been undertaken such as shifting production stock or even shifting to a new cricket species. These challenges with house crickets are confirmed by literature references (Liu et al., 2011, Weissmann et al., 2012).

The study obviously has some weaknesses, since not all recipients of the survey responded and responses were more or less subjective statements. Regardless, we feel that this survey provides some clear indications about the perception of problems by producers and on that basis we can suggest areas where research in disease biology and management in rearing facilities is especially essential. The survey can act as the backbone for more elaborate studies leading to more accurate information about emerging insect diseases in major production insect species (like Table 1 and Table 2 shown here for honeybees and silkworms) and protocols for control of these diseases.

\section{Biosafety aspects}

Insect pathogens are generally specific for invertebrates and do not harm vertebrates. Many pathogens are used in biocontrol of insect pests and are either generally regarded as safe in North America or are qualified presumption of safety in Europe, when intentionally added to food or feed for this purpose (Leuschner et al., 2010; Sundh et al., 2012). Those, that are not, are tested specifically and individually for the presence of toxins or other metabolic compounds and their safety for humans and animals prior to use. Safety of invertebrate pathogens is an intrinsic part of the registration of these agents as biocontrol agents prior to commercialisation. The greatest risk for humans and animals is the emergence of opportunistic microbials in insect rearing systems as a consequence of the disease. Therefore insect diseases should be avoided and controlled, when insects are reared and used for human and animal consumption.

Table 3. Examples from a 2014 survey about diseases in insects produced for food and feed.

$\begin{array}{llll}\text { Production insect } & \text { Disease agent } & \text { Symptoms } & \text { Action } \\ \text { House fly (Musca dometica) } & \text { fungus: Entomophthora spp. } & \text { dead adult flies with spores, epidemic } & \begin{array}{c}\text { cleaning, removal of dead flies, } \\ \text { quarantine }\end{array} \\ \text { Black soldier fly (Hermetia illucens) } & \text { none } & \text { none } & \text { none } \\ \text { House cricket (Acheta domesticus) } & \text { bacteria sp. } & \text { cleaning of cages } \\ & \text { fungus: Metarhizium sp. } & \text { some mortality in population } & \text { quarantine, new breeding stock } \\ & \text { cricket paralysis virus (CrPV) } & \text { collapse of cricket population } & \begin{array}{c}\text { switch to new breeding stock or even } \\ \text { new cricket species }\end{array} \\ & \text { fungus: Beauveria bassiana } & \text { some mortality in population } & \text { cleaning, removal of dead larvae, } \\ \text { Mealworm (Tenebrio molitor) } & & & \text { quarantine }\end{array}$




\section{Prevention and control of insect diseases in production systems}

Problems related to establishing an insect colony for rearing in insectaries, laboratories or in other rearing facilities are well-described by Bartlett $(1984,1994)$ and in MoralesRamos et al. (2014). The number of insects collected from a given locality usually represents only a subset of the total field population. Once the insects are brought into the rearing facility, only some individuals are able to survive and reproduce in the very simplified conditions created for rearing. The genetic diversity in a reared insect population will therefore become significantly smaller than the genetic diversity in the original population living in nature. Practical implications include:

1. Be observant in the production facilities and perform immediate diagnosis, if some insects die from unknown causes, or if the insects do not perform well in general. Make sure to allow the causal agent to develop in/on some individuals for diagnosis. Note symptoms of infected hosts, which is best achieved using both a dissection microscope and a light microscope for glass slides with smears. Allow some infected individuals to dry, while other specimens should be stored in alcohol or freezer. The next step will be to make detailed microscopic observations of spores or other propagules in infected insects keeping in mind that the staining method to be employed will depend on the suspected type of pathogen (Lacey, 2012). Once this has been done, the next step is to consult literature or experts. In many cases, molecular tools may be needed (immune detection by ELISA, or genes detected by PCR) for precise determination of the etiological agent to genus, species or strain level. Be aware that hitherto unknown diseases may appear.

2. Clean production facilities. Optimal rearing conditions are of outmost importance to maintain the health status of the colony. All diseased or strange looking insects should be removed immediately and destroyed. For some diseases like bacteria and fungi, cleaning of equipment and rooms using water, soap and a disinfecting agent are sometimes sufficient. However, in more severe cases, sterilisation with ultraviolet light or discharge of cages, etc., may be necessary. In case of emergency antibiotics should be temporarily used to eliminate bacteria, fungi, or microsporidia. For viruses antivirals or RNAi may be developed for use.

3. Separate parts of the production stock into different facilities and avoid mixing these subpopulations again before it is certain that the disease has been successfully managed. In the case of latent baculovirus infections, even the above mentioned control methods may prove inadequate. As stated by Cory and Myers (2003): 'Understanding, or even consistently demonstrating, baculovirus latency has proven to be elusive, and triggering an active infection from a latent virus may be an unpredictable, stochastic process'. In such cases, the quarantine or cleaning processes will not solely result in sufficient protection of the insect population from latent virus infections, which can spread later.

4. Maintain wide genetic variability in populations. We suggest introducing newly captured individuals or populations into the old colony in insectaries at regular intervals, in order to get new alleles into the existing population being bred and by that enlarge the genetic basis of the reared population. This will only be effective when enforced mating takes place between newly introduced individuals and residents. This, of course, poses problems in terms of a risk of new disease introduction from the environment, so it is advisable to keep new breeding stock insects in quarantine for some time. The behaviour of the recently introduced individuals should be studied for one or two generations, in order to see if they are carriers of diseases. Particularly dangerous are vertically transmitted diseases, which are not readily identifiable in the population.

5. Maintain several different lines for reproduction in a population, as a reservoir of genetic variability. These can be cross-bred in order to produce hybrid eggs, to create stronger and more productive individual compared to parental lines (Grekov et al., 2005). It is important to determine the minimum number of reproducers necessary to maintain parental lines. For example, in the silkworm it is suggested to maintain each strain or line starting with at least 25 different egg batches laid by 50 fertile reproductive partners (male and female moths). From the subsequent bulk rearing, 50 individuals will be chosen again to perpetuate the following generation. These reproduction steps are particularly important and should be performed separately in a dedicated sector of the rearing plant (Cappellozza et al., 2013).

\section{Conclusions}

Insects produced for food and feed are subjected to infections by several kinds of microorganisms: viruses, bacteria, microsporidia, fungi and nematodes (carrying pathogenic bacteria). Each group of insect pathogens has its unique biological characteristics requiring different approaches for control.

For honeybees and silkworms centuries of knowledge about emerging insect diseases exist and lessons learned from these insects should be implemented for control of diseases in insects produced for food and feed. The current disease pressure in the four most used insects in production for food and feed varies, but based on experiences from honeybees and silkworms we can expect new diseases to emerge in all insect production systems over time.

Diagnosis manuals and suggestions for control of diseases with specific reference to insects produced for food and 
feed are lacking. Of high relevance are protocols for disease monitoring and disease control in house flies, black soldier flies, mealworms, and house crickets. Protocols for other insect species produced for food and feed should of course be added over time.

Research needs to include basic studies on emerging insect diseases: biological and genetic characterisation, phylogeny, host range, transmission, persistence, epidemic potential and safety for animals including humans. Applied studies should include: systematic comparisons of different methods for maintaining hygiene and for prevention of diseases, and systematic comparisons of methods for controlling diseases when they occur.

Also issues related to the role of the microbial community in the insects, their diet and rearing facilities are of importance to prevent emergence of pathogens. Likewise, studies related to such microflora and their metabolites have importance to assess the microbial hazard for consumers of insect based products, an issue which is not treated within the topic of this review.

\section{Acknowledgements}

Annette Bruun Jensen and Jørgen Eilenberg are supported by the grant 32726 from the Velux Foundation and by the DANIDA grant 13-06KU (GREEiNSECT). We are grateful to respondents to our questionnaire.

\section{References}

Adamo, S., 1999. Evidence for adaptive changes in egg laying in crickets exposed to bacteria and parasites. Animal Behaviour 57: 117-124. Adams, J.R. and Bonami, J.R., 1991. Atlas of invertebrate viruses. CRC Press, Boca Raton, FL, USA, 684 pp.

Anderson, R.D., Bell, A.S., Blanford, S., Paaijmans, K.P. and Thomas, M.B., 2011. Comparative growth kinetics and virulence of four different isolates of entomopathogenic fungi in the house fly (Musca domestica L.). Journal of Invertebrate Pathology 107: 179-184.

Anderson, R.D., Blanford, S., Jenkins, N.E. and Thomas, M.B., 2013. Discriminating fever behavior in house flies. PLoS ONE 8: e62269.

Barnes. A.I. and Siva-Jothy, M.T., 2000. Density-dependent prophylaxis in the mealworm beetle Tenebrio molitor L. (Coleoptera: Tenebrionidae): cuticular melanization is an indicator of investment in immunity. Proceedings of the Royal Society of London 267: 177-182.

Bartlett, A.C., 1984. Genetic changes during insect domestication. In: King, E.G. and Leppla, N.C. (eds.) Advances and challenges in insect rearing. Agricultural Research Service, United States Department of Agriculture, New Orleans, LA, USA, pp. 2-8.

Bartlett, A.C., 1994. Maintaining genetic diversity in laboratory colonies of parasites and predators In: Narang, S.K., Bartlett, A.C. and Faust, R.M. (eds.) Applications of genetics to arthropods of biological control significance. CRC Press, Boca Raton, FL, USA, pp. 133-146.
Bassi, A., 1835. Del Mal del Segno, Calcinaccio o Moscardino. Parte I. Dalla Tipografia Orcesi, Lodi, Italy, pp. 60.

Bassi, A., 1836. Del Mal del Segno, Calcinaccio o Moscardino. Parte II. Dalla Tipografia Orcesi, Lodi, Italy, pp. 85.

Blanford, S. and Thomas, M.B., 2001. Adult survival, maturation, and reproduction of the desert locust Schistocerca gregaria infected with the fungus Metarhizium anisopliae var. acridium. Journal of Invertebrate Pathology 78: 1-8.

Boomsma, J.J., Jensen, A.B., Meyling, N.V. and Eilenberg, J., 2014. Evolutionary networks between insect pathogenic fungi. Annual Review of Entomology 59: 467-485.

Bravo, A., Likitvivatanavong, S., Gill, S.S. and Soberon, M., 2011. Bacillus thuringiensis: a story of successful bioinsecticide. Insect Biochemistry and Molecular Biology 41: 423-431.

Brown, I.M., Shapiro-Ilan, D.I. and Gaugler, R.R., 2006. Entomopathogenic nematode infectivity enhancement using physical and chemical stressors. Biological Control 39: 147-153.

Butt, T.M., Hajek, A.E. and Humber, R.A., 1996. Gypsy moth immune defenses in response to hyphal bodies and natural protoplasts of entomophthoralean fungi. Journal of Invertebrate Pathology 68: 278-285.

Cappellozza, S., Saviane, A. and Toso, L., 2013. La collezione di germoplasma di baco da seta (Bombyx mori L.) e gelso appartenente all'Unità di apicoltura e bachicoltura di Bologna, sede di Padova. In: D'Andrea, F. (ed.) Conservazione biodiversità, gestione banche dati e miglioramento genetico - Biodati, Volume II. Edizioni Nuova Cultura, Roma, Italy, pp. 961.

Chen, P.P., Wongsiri, S., Jamyanya, T., Rinderer, T.E., Vongsamanode, S., Matsuka, M., Sylvester, H.A. and Oldroyd, B.P., 1998. Honey bees and other edible insects used as human food in Thailand. American Entomologists 44: 24-29.

Cohen A.C., 2004 Microbes in the diet setting In: Cohen, A.C. (ed.) Insect diets: science and technology. CRC Press, Washington, DC, USA, pp. 229-230.

Cory, J.S. and Myers, J.H., 2003. The ecology and evolution of baculoviruses. Annual Review of Ecology, Evolution and Systematics 34: 239-272.

De Graaf, D.C., Alippi, A.M., Antúnez, K., Aronstein, K.A., Budge, G., De Koker, D., De Smet, L., Dingman, D.W., Evans, J.D., Foster, L.J., Fünfhaus, A., Garcia-Gonzalez, E., Gregorc, A., Human, H., Murrays, K.D., Nguyen, B.K., Poppinga, L., Spivak, M., Vanengelsdorp, D., Wilkins, S. and Genersch, E., 2013. Standard methods for American foulbrood research. Journal of Apicultural Research 52, DOI: http:// dx.doi.org/10.3896/IBRA.1.52.1.11.

De Miranda, J.R., Bailey, L., Ball, B.V., Blanchard, P., Budge, G., Chejanovsky, N., Chen, Y-P., Van Dooremalen, C., Gauthier, L., Genersch, E., De Graaf, D., Kramer, M., Ribière, M., Ryabov, E., De Smet, L. and Van der Steen, J.J.M., 2013. Standard methods for virus research in Apis mellifera. Journal of Apicultural Research 52, DOI: http://dx.doi.org/10.3896/IBRA.1.52.4.22.

Defoliart, G.R., 1994. Edible insects as minilivestock. Biodiversity and Conservation 4: 306-321

Dubovskiy, I.M., Whitten, M.M.A., Yaroslavtseva, O.N., Greig, C., Kryukov, V.Y., Grizanova, E.V., Mukherjee, K., Vilncinskas, A., Glupov, V.V. and Butt, T.M., 2013. Can insects develop resistance to insect pathogenic fungi? PLoS ONE 8: e60248. 
El Boushy, A.R., 1991. House-fly pupae as poultry manure converters for animal feed: a review. Bioresource Technology 38: 45-49.

Fauce, K.A. and Owens, L., 2008. The use of insects as a bioassay for Penaeus merguiensis densovirus (PmergDNV). Journal of Invertebrate Pathology 98: 1-6.

Fedhila, S., Buisson, C., Dussurget, O., Serror, P., Glomski, I.J., Liehl, P., Lereclus, D. and Nielsen-LeRoux, C., 2010. Comparative analysis of the virulence of invertebrate and mammalian pathogenic bacteria in the oral insect infection model Galleria mellonella. Journal of Invertebrate Pathology 103: 24-29.

Forsgren, E., Budge, G.E., Charrière, J.D. and Hornitzky, M.A.Z., 2013. Standard methods for European foulbrood research. Journal of Apicultural Research 52, DOI: http://dx.doi.org/10.3896/ IBRA.1.52.1.12.

Fries, I., Chauzat, M-P., Chen, Y-P., Doublet, V., Genersch, E., Gisder, S., Higes, M., McMahon, D.P., Martín-Hernández, R., Natsopoulou, M., Paxton, R.J., Tanner, G., Webster, T.C., Williams, G.R., 2013. Standard methods for Nosema research. Journal of Apicultural Research 52, DOI: http://dx.doi.org/10.3896/IBRA.1.52.1.14.

Fuxa, J.R., Sun J.Z., Weidner, E.H. and LaMotte, L.R., 1999. Stressors and rearing diseases of Trichoplusia ni: evidence of vertical transmission of NPV and CPV. Journal of Invertebrate Pathology 74: 149-155.

Geden, G.J., Steenberg, T., Lietze, V.U. and Boucias, D.G., 2011. Salivary gland hypertrophy virus of house fly in Denmark: prevalence, host range, and comparison with a Florida isolate. Journal of Vector Ecology 36: 231-238.

Georgis, R., Mullens, B.A. and Meyer, J.A., 1987. Survival and movement of insect parasitic nematodes in poultry manure and their infectivity against Musca domestica. Journal of Nematology 19: 292-295.

Gray, D.A., 1997. Sex differences in susceptibility of house crickets, Acheta domesticus, to experimental infection with Serratia liquefaciens. Journal of Invertebrate Pathology 71: 288-289.

Grekov, D., Kipriotis, E. and Tzenov, P., 2005. Sericulture training manual. Komotini, Greece, 320 pp.

Harrison, R. and Hoover, K., 2012. Baculovirus and other occluded insect virus. In: Vega, F.E. and Kaya, H.K. (eds.) Insect pathology ( $2^{\text {nd }}$ Ed.). Elsevier, Amsterdam, the Netherlands, pp.73-132.

Higes, M., Martin-Hernandez, R., Botias, C., Bailon, E.G., GonzalesPorto, A.V., Barrios, L., Del Nozal, M., Bernal, J.L., Jimenez, J.J., Palencia, P.G., Meana, A., 2008. How natural infection by Nosema ceranae causes honeybee colony collapse. Environmental Microbiology 10: 2659-2669.

Hughes, D.S., Possee, R.D. and King, L.A., 1997. Evidence for the presence of a low level, persistent baculovirus infection of Mamestra brassicae insects. Journal of General Virology 78: 1801-1805.

Hwangbo, J., Hong, E.C., Jang, A., Kang, H.K., Oh, J.S., Kim, B.W. and Park, B.S., 2009. Utilization of house fly-maggots, a feed supplement in the production of broiler chickens. Journal of Environmental Biology 30: 609-614.

Jakob, N.J., Kleespies, R.G., Tidona, C.A., Müller, K., Gelderblom, H.R. and Darai, G., 2002. Comparative analysis of the genome and host range characteristics of two iridoviruses: Chilo iridescent virus and a cricket iridovirus isolate. Journal of General Virology 83: 463-470.
James, R.R. and Li, Z., 2012. From silkworm to bees: diseases of beneficial insects. In: Vega, F.E. and Kaya H.K. (eds.) Insect pathology ( $2^{\text {nd }}$ Ed.). Elsevier, Amsterdam, the Netherlands, pp. 425-460.

Jensen, A.B., Aronstein, K., Flores, J.M., Vojvodic, S., Palacio, M.A. and Spivak, M., 2013. Standard methods for fungal brood disease research. Journal of Apicultural Research 52, DOI: http://dx.doi. org/10.3896/IBRA.1.52.1.13.

Jensen, A.B., Eilenberg, J. and Lastra, C.L., 2009. Differential divergencies of obligately insect-pathogenic Entomophthora species from fly and aphid hosts. FEMS Microbiology Letters 300: 180-187.

Jensen, A.B., Thomsen, L. and Eilenberg, J., 2006. Value of host range, morphological, and genetic characteristics within the Entomophthora muscae species complex. Mycological Research 110: 941-950.

Jurat-Fuentes, J.L. and Jackson, T.A., 2012. Bacterial entomopathogens. In: Vega, F.E. and Kaya, H.K. (eds.) Insect pathology (2 ${ }^{\text {nd }}$ Ed.). Elsevier, Amsterdam, the Netherlands, pp. 266-349.

Kalsbeek, V., Mullens, B.A. and Jespersen, J.B. 2001. Field studies of Entomophthora (Zygomycetes: Entomophthorales) - induced behavioral fever in Musca domestica (Diptera: Muscidae) in Denmark. Biological Control 21: 264-271.

King, A.M.Q., Adams, M.J., Carstens, E.B. and Lefkowitz, E.J. (eds.), 2012. Virus taxonomy: ninth report of the international committee on taxonomy of viruses. Elsevier, Amsterdam, the Netherlands, 1327 pp.

Kleespies, R.G., Tidona, C.A. and Darai, G., 1999. Characterization of a new iridovirus isolated from crickets and investigations on the host range. Journal of Invertebrate Pathology 73: 84-90.

Kodama, R., 2001. Bacterial diseases and countermeasures. In: Hamamura, Y. (ed.) Silkworm rearing on artificial diet. Science Publishers, pp. 162-221.

Kok, I.P., Skuratovskaya, I.N., Strokovskaya, L.I., Miryuta, N.Yu. and Alekseenko, L.P., 1983. Detection of integration of baculovirus and cellular genomes (DNA) during latent infection. Molecular Biology 34: 67-69.

Kukan, B., 1999. Vertical transmission of nucleopolyhedrovirus in insects. Journal of Invertebrate Pathology 74: 103-111.

Lacey, L. (ed.), 2012. Manual of techniques in invertebrate pathology ( $2^{\text {nd }}$ Ed.). Academic Press, Amsterdam, the Netherlands, 484 pp.

Lange, C.E. and Lord, J.C., 2012. Protistan entomopathogens. In: Vega, F.E. and Kaya, H.K. (eds.) Insect pathology ( $2^{\text {nd }}$ Ed.). Elsevier, Amsterdam, the Netherlands, pp. 367-394.

Lastra, C.C.L., Siri, A., Garcia, J.J., Eilenberg, J. and Humber, R.A., 2006. Entomophthora ferdinandii (Zygomycetes: Entomophthorales) causing natural infections of Musca domestica (Diptera: Muscidae) in Argentina. Mycopathologia 161: 251-254.

Leuschner, H.H., Robinson, T.P., Hugas, M., Cocconcelli, P.S., Richard-Forget, F., Klein, G. Licht, T.R. Nguyen-The, C. Querol, A. Richardson, M. Suarez, J.E. Thrane, U.; Vlak, J.M. and Von Wright, A., 2010. Qualified presumption of safety (QPS): a generic risk assessment approach for biological agents notified to the European Food Safety Authority (EFSA). Trends in Food Science and Technology 21: 425-435. 
Lewis, E.E. and Clarke, D.J., 2012. Nematode parasites and entomopathogens. In: Vega, F.E. and Kaya, H.K. (eds.) Insect pathology (2 $2^{\text {nd }}$ Ed.). Elsevier, Amsterdam, the Netherlands, pp. 395-424.

Liehl, P., Blight, M., Vodovar, N., Boccard, F. and Lemaitre, B., 2006. Prevalence of local immune response against oral infection in a Drosophila/Pseudomonas infection model. PLoS Pathogens 2: e56. Lietze, V.U., Schneider, G., Prombiboon, P. and Bouchias, D.G., 2010. The detection of Bacillus thuringiensis in mass rearing of Cactoblastis cactorum (Lepidoptera: Pyralidae). Florida Entomologist 93: 385-390.

Lietze, V.U., Sims, K.R., Salem, T.Z., Geden, C.J. and Boucias, D.G., 2009. Transmission of MdSGHV among adult house flies, Musca domestica (Diptera: Muscidae), occurs via oral secretions and excreta. Journal of Invertebrate Pathology 101: 49-55.

Liu, K., Li, Y., Jousset, F-X., Zadori, Z., Szelei, J., Yu, Q., Pham, H.T., Lépine, F., Bergoin, M. and Tijssen, P., 2011. The Acheta domesticus densovirus, isolated from the European house cricket, has evolved an expression strategy unique among parvoviruses. Journal of Virology 85: 10069-10078.

Lu, Y.L., 1991. Silkworm diseases. FAO Agricultural Services Bulletin 73/4. FAO, Rome, Italy, 77 pp.

Maniania, N.K., Vaughan, L.J. and Ouna, E., 2008. Susceptibility of immature stages of the locust Schistocerca gregaria and Locusta migratoria migratorioides to the microsporidium Johenrea locustae and effects of infection of feeding and fertility in the laboratory. Biocontrol Science and Technology 18: 913-920.

Meyling, N.V. and Eilenberg, J., 2006. Occurrence and distribution of soil borne entomopathogenic fungi within a single organic agroecosystem. Agriculture, Ecosystems \& Environment 113: 336-341.

Miryuta, N., Yu., Strokovskaya, L.I., Kok, I.P. and Skuratovskaya, I.N., 1985. Detection of baculovirus genome covalently bound to cellular DNA in greater wax moth. Biopolimery i Kletka 1: 106-108.

Morales-Ramos, J.A., Guadalupe Rojas, M. and Shapiro-Ilan, D.I. (eds.), 2014. Mass production of beneficial organisms. Invertebrates and entomopathogens. Academic Press, Amsterdam, the Netherlands, $742 \mathrm{pp}$.

Moret, Y. and Siva-Jothy, M.T., 2003. Adaptive innate immunity? Responsive-mode prophylaxis in the mealworm beetle, Tenebrio molitor. Proceedings of the Royal Society of London B 270: 2475-2480.

Mukherjee, K., Hain,T., Fischer, R., Chakraborty, T. and Vilcinskas, A., 2013. Brain infection and activation of neuronal repair mechanisms by the human pathogen Listeria monocytogenes in the lepidopteran model host Galleria mellonella. Virulence 4: 324-332.

Mullens, B.A., Rodriguez, J.L. and Meyer, J.A., 1987. An epizootiological study of Entomophthora muscae in muscoid fly populations in Southern California poultry facilities. Hilgardia 55: 1-41.

Myers, J.H., Malakar, R. and Cory, J.S., 2000. Sublethal nucleopolyhedrovirus infection effects on female pupal weight, egg mass size, and vertical transmission in gypsy moth (Lepidoptera: Lymantriidae). Environmental Entomologist 29: 1268-1272.

Nielsen, O. and Philipsen, H., 2004. Seasonal population dynamics of inoculated and indigenous steinernatid nematodes in an organic cropping system. Nematology 6: 901-909.
Nielsen-LeRoux, C., Gaudriault S., Ramarao, N., Lereclus, D. and Givaudan, A., 2012. How the insect pathogen bacteria Bacillus thuringiensis and Xenorhabdus/Photorhabdus occupy their hosts. Current Opinion in Microbiology 15: 220-231.

Noonin, C., Jiravanichpaisal, P., Söderhäll, I., Merino, S., Tomás, J.M. and Söderhäll, K., 2011. Melanization and pathogenicity in the insect, Tenebrio molitor, and the crustacean, Pacifastacus leniusculus, by Aeromonas hydrophila AH-3. PLoS ONE 5: e15728.

Ouedraogo, R.M., Goettel, M.S. and Brodeur, J., 2004. Behavioral thermoregulation in the migratory locust: a therapy to overcome fungal infection. Oecologia 138: 312-319.

Owens, L., La Fauce, K. and Claydon, K., 2011. The effect of Penaeus merguiensis densovirus on Penaeus merguiensis production in Queensland, Australia. Journal of Fish Diseases 34: 509-515.

Pasteur, L., 1870. Études sur la maladie des vers à soie (Volume 2). Gauthier-Villars, Paris, French, 670 pp.

Rangel, D.E.N., Braga, G.U.L., Flint, S.D., Anderson, A.J. and Roberts, D.W., 2004. Variations in UV-B tolerance and germination speed of Metarhizium anisopliae conidia produced on insects and artificial substrates. Journal of Invertebrate Pathology 87: 77-83.

Rantala, M.J., Viitaniemi, H. and Roff, D.A., 2010. Effects of inbreeding on potential and realized immune responses in Tenebrio molitor. Parasitology 138: 906-912.

Roy, H.E., Steinkraus, D.C., Eilenberg, J., Hajek, A.E. and Pell, J.K., 2006. Bizarre interactions and endgames: Entomopathogenic fungi and their arthropod hosts. Annual Review of Entomology 51: 331-357.

Salem, T.Z., Garcia-Maruniak, A., Lietze, V.U., Maruniak, J.E. and Boucias, D.G., 2009. Analysis of transcripts from predicted open reading frames of Musca domestica salivary gland hypertrophy virus. Journal of General Virology 90: 1270-1280.

Shapiro-Ilan, D.I., Mbata, G.N., Nguyen, K.B., Peat, S.M., Blackburn, D. and Adams, B.J., 2009. Characterization of biocontrol traits in the entomopathogenic nematode Heterorhabditis georgiana (Kesha strain) and phylogenetic analysis of the nematode's symbiotic bacteria. Biological Control 51: 377-387.

Siri, A., Scorsetti, A.C., Dikholz, V.E. and Lastra, C.C.L., 2005. Natural infections caused by the fungus Beauveria bassiana as a pathogen of Musca domestica. BioControl 50: 937-940.

Solter, L.F. and Bechnel, J.J., 2012. Microsporidian entomopathogens. In: Vega, F.E. and Kaya, H.K. (eds.) Insect pathology ( $\left.2^{\text {nd }} E d.\right)$. Elsevier, Amsterdam, the Netherlands, pp. 221-264.

Song, L., Gao, M., Dai, S., Wu, Y., Yi, D. and Li, R., 2008. Specific activity of a Bacillus thuringiensis strain against Locusta migratoria manilensis. Journal of Invertebrate Pathology 98: 169-176.

Starks, P.T., Blackie, C.A. and Seeley, T.D., 2000. Fever in honeybee colonies. Naturwissenschaften 87: 229-231.

Sun, B.D. and Liu, X.Z., 2008. Occurrence and diversity of insectassociated fungi in natural soils in China. Applied Soil Ecology 39: 100-138.

Sundh, I., Vicks, A. and Goettel, M.S. (eds.), 2012. Beneficial microorganisms in agriculture, food and the environment: safety assessment and regulation. CABI, Oxfordshire, UK, 360 pp. 


\section{J. Eilenberg et al.}

Szelei, J., Woodring, J, Goettel, M.S., Duke, G., Jousset, F.X., Liu, K.Y., Zadori, Z., Li, Y., Styer, E., Boucias, D.G., Kleespies, R.G., Bergoin, M. and Tijsen, P., 2011. Susceptibility of North-American and European crickets to Acheta domesticus densovirus (AdDNV) and associated epizootics. Journal of Invertebrate Pathology 106: 394-399.

Tokarev, Y.S., Levchenko, M.V., Naumov, A.M., Senderskiy, I.V. and Lednev, G.R., 2011. Interaction of two insect pathogens, Paranosema locustae (Protista: Microsporidia) and Metarhizium acridium (Fungi: Hypocreales), during a mixed infection of Locusta migratoria (Insecta: Orthoptera) nymphs. Journal of Invertebrate Pathology 106: $336-338$

Tong, L., Yu, X. and Liu, H., 2011. Insect food for astronauts: gas exchange in silkworms fed on mulberry and lettuce and the nutritional value of these insects for human consumption during deep space flight. Bulletin of Entomological Research 101: 613-622.

Vallet-Gely, I., Lemaitre, B. and Boccard, F., 2008. Bacterial strategies to overcome insect defences. Nature Review Microbiology 6: 302-313.

Van Frankenhuyzen, K., 2009. Insecticidal activity of Bacillus thuringiensis crystal proteins. Journal of Invertebrate Pathology 101: 1-16.

Van Huis, A., Van Itterbeck, J., Klunder, H., Mertens, E., Halloran, A., Muir, G. and Vantomme, P., 2013. Edible insects: future prospects for food and feed security. FAO Forestry Paper 171. Food and Agricultural Organization of The United Nations, Rome, Italy, $187 \mathrm{pp}$.

Vega, F.E. and Kaya, H.K. (eds.), 2012. Insect pathology (2 ${ }^{\text {nd }}$ Ed.). Elsevier, Amsterdam, the Netherlands, 508 pp.
Vega, F.E., Meyling, N.V., Luangsaard, J.J. and Blackwell, M., 2012. Fungal entomopathogens. In: Vega, F.E. and Kaya, H.K. (eds.) Insect pathology, $2^{\text {nd }}$ edition. Elsevier, Amsterdam, the Netherlands, pp. 171-220.

Wanaratana, S., Amonsin, A., Chaisingh, A., Panyim, S., Sasipreeyajan, J., Pakpinyo, S., 2013. Experimental assessment of houseflies as vectors in avian influenza subtype H5N1 transmission in chicken. Avian Diseases 37: 266-272.

Watanabe, H., 2002. Genetic resistance of the silkworm to viral diseases. Current Science 8: 439-446.

Weissmann, D.B., Gray, D.A., Pham, H.T. and Tijsen, P., 2012. Billions and billions sold: pet-feeder crickets (Orthoptera: Gryllidae), commercial cricket farms, an epizootic densovirus, and government regulation make for a potential disaster. Zootaxa 3504: 67-88.

Wilson, K., Thomas, M.B., Blanford, S., Doggert, M., Simpson, S.J. and Moore, S.L., 2002. Coping with crowds: density-dependent disease resistance in desert locusts. Proceedings of the National Academy of Sciences 99: 5471-5475.

Wu, S.J. and Dean, D.H., 1996. Functional significance of loops in the receptor binding domain of Bacillus thuringiensis CryIII $\delta$-endotoxin. Journal of Molecular Biology 255: 628-640.

Zimmer, C.R., De Castro, L.L.D., Pires, S.M., Menezes, A.M.D., Ribeiro, P.B.R. and Leite, F.B.L., 2013. Efficacy of entomopathogenic bacteria for control of Musca domestica. Journal of Invertebrate Pathology 114: 241-244. 